\title{
OPTIMIZATION OF GROUP COHESION THROUGH RESTRUCTURING SOCIAL NETWORKS BY USING MOTOR SKILL GAMES IN PHYSICAL EDUCATION LESSON
}

\author{
Mijaică Raluca ${ }^{{ }^{*}}$ \\ ${ }_{n}^{1}$ Transilvania" University of Braşov, 29, Eroilor Street, 500036 Romania
}

Keywords: physical-education lesson, motor skill games, group cohesion

\begin{abstract}
The class of pupils has all the features specific to a primary social group; and highcohesion groups are considered to be capable of establishing much easier their performance standards. The premise of our experimental study started from the belief that physical education is one of the disciplines which might substantially contribute to the pupils' personal and social development. The experiment we conducted, consisted in implementing, in the physical-education lessons, a set of 6 categories of motor skill games, applied to the $9^{\text {th }}-10^{\text {th }}$ grades, for three semesters, with a view to improving the group cohesion, as well as the participating pupils' interpersonal relations and personality traits. The research data highlighted the efficiency of our teaching approach, leading to the conclusion that the higher cohesion of the class of pupils, the improvement of the interpersonal relations, and the development of the personality traits - all these may be achieved by adequately taking over several categories of motor skill games, originating in non-formal education.
\end{abstract}

\section{Introduction}

The small social group is characterized by the existence of a certain number of persons, of a common goal towards which the efforts of the group members are targeted, of a status network (the individual's basic position in society), (Lindsey, as cited in Golu, 2002, p.124), of a norm- and value-system acknowledged and accepted by all group members, governing the behaviour thereof, according to the group interests.

The class of pupils is a specific workgroup, consisting of a number of members equal to each other (pupils) and of an animator (teacher). Therein, an amount of relations coexist, which are officially regulated by the type of the task and by the given operating rules. At class level, once with its transformation into a social group, each pupil acquires a status, positive, negative, or null, which is indicative of popular, accepted, indifferent, or marginalized (affectively

\footnotetext{
*E-mail: raluca_mijaica@unitbv.to, tel.0735844294
} 
isolated) subjects within the group (Bogáthy, 2004, p. 255). This status displays a development, and, most times, a restructuring, depending on each member's manner of personal involvement in the achievement of both imposed and nonimposed objectives targeted by the class of pupils.

Each class of pupils is characterized by a certain cohesion level. Cohesion expresses the global attraction exercised by the group upon its members, by means of the control function, of the pressure towards uniformity, and of the members' affective integration, which results in forming a sense of "us", which prevails on the tendencies of individual autonomy (Marica, 2008, p. 106). Cohesion is the outcome of the action of varied categories of factors, related to the fundamental human needs: integration, self-assertion, or social recognition; necessities of affection, communication, or protection; those of ascendance, or dependence, etc.; and all these motivational configurations specific to each person, can be fulfilled in a differentiated manner, to an extent depending on the structural and functional qualities of the group, as a system.

High-cohesion groups are capable of establishing more easily performance standards, and of offering a wider range of rewards to their members. Shaw (1997, pp. 98-112; 2000, p. 56) has proven that highly cohesive groups are cooperative and friendly, using a democratic form of behaviour control. On the contrary, as regards small-cohesion groups, the same author has noticed that their constitutive members are hostile and aggressive to each other, as well as thrilled at their colleagues' mistakes, and the decision-making style is autocratic. Likewise, and Sheriff (1976, p. 108) has noticed that intergroup competition might entail a general-rule-raising practice. Cohen (1994, pp. 135), has remarked that, in some situations, the group cohesion might interfere with the information analysis and information character; and the cohesive group members are often averse to the contributions brought by other members, outside the group.

In order to increase a group's cohesion, an action into which our research falls, in its turn, group members must undergo a socializing action. By socializing we understand their going through a process of norm-, principle-, and value-internalization, of social-rule-acquisition, etc., which is possible by the motor learning act, knowing that one of the functions associated to school physical education is socialization Dragnea, (2000, p. 56), respectively the social-norm, and value-assimilation.

\section{Material and methods}

The main premise of this research originates in the fact that physical education is an integral part of the concept of education, and the socializing action constitutes a favourable premise for educational activities, in general. Ongoing relations of functional complementariness and interconditioning arise between education and socialization, and the functions and goals of education - implicitly, those of physical education - act as the individuals' means of social integration and participation in the social-relation system (Basiliade, 1976, p. 227). 
The hypothesis underlying this research is that the improvement of the interpersonal relations in the class of pupils, as well as the development of the constituent members' personality traits, by covering, within the physicaleducation lessons, several specific activities of multivalent game, in educational terms, significantly improves class cohesion.

Table 1 Centralizer of the amount of time assigned to the categories of motora skill games, in the physical-education lesson, throughout the research

\begin{tabular}{|c|c|c|c|c|c|}
\hline \multirow{4}{*}{ No. } & \multirow{4}{*}{$\begin{array}{c}\text { Categories of } \\
\text { non-formal } \\
\text { games }\end{array}$} & \multicolumn{4}{|c|}{ Experimental class } \\
\hline & & \multicolumn{2}{|c|}{$\begin{array}{c}9^{T H} \text { GRADE/SCHOOL YEAR } \\
2011-2012 \\
\end{array}$} & \multicolumn{2}{|c|}{$\begin{array}{c}10^{T H} \text { GRADE/SCHOOL } \\
\text { YEAR } 2012 \text { - } 2013\end{array}$} \\
\hline & & Semester I & Semester II & Semester I & Semester II \\
\hline & & - & $\begin{array}{c}\text { Number of } \\
\text { experiential } \\
\text { structures/ } \\
\text { assigned } \\
\text { min/hours } \\
\end{array}$ & $\begin{array}{l}\text { Number of } \\
\text { experiential } \\
\text { structures/ } \\
\text { assigned } \\
\text { min/hours } \\
\end{array}$ & $\begin{array}{l}\text { Number of } \\
\text { experiential } \\
\text { structures/ } \\
\text { assigned } \\
\text { min/hours } \\
\end{array}$ \\
\hline 1 & $\begin{array}{l}\text { Games increasing } \\
\text { the group } \\
\text { members' } \\
\text { knowledge and } \\
\text { awareness of } \\
\text { each other }\end{array}$ & \multirow{4}{*}{ 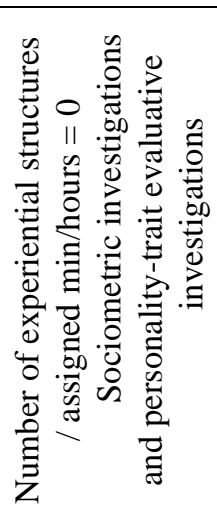 } & $\begin{array}{c}6 \text { / 60min / } \\
\text { 1hour }\end{array}$ & $2 / 15 \min$ & \\
\hline 2 & $\begin{array}{l}\text { Physical-contact } \\
\text { games }\end{array}$ & & $\begin{array}{c}7 / 70 \mathrm{~min} / \\
1: 10\end{array}$ & $4 / 40 \mathrm{~min}$ & $\begin{array}{l}8 / 80 \mathrm{~min} / \\
1: 20\end{array}$ \\
\hline 3 & $\begin{array}{l}\text { Games increasing } \\
\text { mutual } \\
\text { confidence }\end{array}$ & & $\begin{array}{c}9 / 90 \mathrm{~min} / \\
1: 30\end{array}$ & $\begin{array}{l}6 / 60 \min / \\
\text { 1hour }\end{array}$ & $\begin{array}{l}11 / 110 \mathrm{~min} / \\
1: 50\end{array}$ \\
\hline 4 & $\begin{array}{l}\text { Team-activity } \\
\text { building games }\end{array}$ & & $\begin{array}{c}6 / 60 \mathrm{~min} / \\
\text { 1hour }\end{array}$ & $\begin{array}{l}\text { 7/70min / } \\
1: 10\end{array}$ & $\begin{array}{l}\text { 7/70min / } \\
1: 10\end{array}$ \\
\hline
\end{tabular}

\begin{tabular}{|c|c|c|c|c|c|}
\hline 5 & $\begin{array}{l}\text { Games } \\
\text { developping } \\
\text { communication } \\
\text { and cooperation }\end{array}$ & & $\begin{array}{c}9 / 90 \mathrm{~min} / \\
1: 30\end{array}$ & $\begin{array}{l}6 \text { / 60min / } \\
\text { 1hour }\end{array}$ & $\begin{array}{l}15 / 150 \mathrm{~min} / \\
2: 30\end{array}$ \\
\hline 6 & $\begin{array}{l}\text { Environment- } \\
\text { protection games }\end{array}$ & & $\begin{array}{c}2 / 15 \min + \\
1 \text { activity / } \\
120 \mathrm{~min} / 2 \\
\text { hours }\end{array}$ & - & $\begin{array}{l}1 / 10 \mathrm{~min}+ \\
1 \text { activity / } \\
120 \mathrm{~min} / 2 \\
\text { hours }\end{array}$ \\
\hline & & - & $\begin{array}{c}39+1 \text { activity } \\
=8 \text { hours and } \\
10 \mathrm{~min}\end{array}$ & $\begin{array}{l}25=4 \text { hours } \\
\text { and } 5 \text { min }\end{array}$ & $\begin{array}{l}42+1 \text { activity } \\
=8 \text { hours and } \\
50 \text { min }\end{array}$ \\
\hline \multicolumn{2}{|c|}{ Total of assigned hours } & \multicolumn{4}{|c|}{21 hours and $5 \mathrm{~min}$} \\
\hline
\end{tabular}

For the experimentally implemented methodology, a teaching strategy of programming/scheduling several experiential motor learning units/structures, with contents including 6 categories of games (table 1), with a total of 112 basic games, to which different practicing variants were added (depending on the 
operational object pursued, on the complexity of the activity, on its duration, venue, level of risk, etc.). The games were applied in an experimental class, lesson by lesson, over two study years, respectively over three semesters. Cumulatively, as regards the time duration assigned to these activities, we consumed, out of the lessons, the times listed in table 1.

The experiment we conducted, was of the type pre-test - post-test (or model of „interrupted series, with control groups, with inequivalent groups”, according to Epuran, 2005, p. 255 - 256), following the scheme:

$\begin{array}{llllll}\text { Experimental group } & \text { test } 1 & \text { V.I. } & \text { test } 2 & \text { V.I. } & \text { test } 3 \\ \text { Control group } & \text { test } 1 & - & \text { test } 2 & - & \text { test } 3\end{array}$

(where V.I. is the independent variable of the experiment, respectively the methodology consisting in the range of games implemented in the physicaleducation lesson; and the behaviour of the two groups is compared)

As regards the research subjects, on the horizontal, as tuition tier, we opted for implementing our methodology, at the level of the $9^{\text {th }}$ grades (30 pupils in the experimental class, and 30 pupils in the control class), classes selected in the school year 2011-2012 (mentioning that the actual experiment started in the $2^{\text {nd }}$ semester of the academic year, after the subjects had adapted to their new school environment); and for continuing the approach with the same classes, respectively subjects who completed the school year 2012-2013, in the $10^{\text {th }}$ grade (both $1^{\text {st }}$ and $2^{\text {nd }}$ semesters), at „Andrei Șaguna” National College of Brașov.

In terms of the method for testing the interpersonal relations, for the targeted classes, we resorted to the sociometric method (Matei, 1981, p. 108), The questionnaires (made up of eight questions) were applied to the members of both experimental and control classes. The results were processed by the sociometric technique, and were centralized by drafting sociometric matrices (which show the centralized data of the number and values afferent to the obtained preferences and rejections). Based thereon, the sociometric-status index (Iss) and preferential-status index (Isp) were calculated for each subject/evaluation stage. With these results, the cohesion-coefficient (Cgr)/stage of the experimental and control classes, was calculated. Likewise, the data centralized in the sociometric matrices, were transposed, according to the sociometric technique, into sociograms of the choices and rejections/stage. They allowed/assessment stage, to detect the dyads, triads, chains or other types of interpersonal relations, if appropriate. As regards the graphical-presentation form of the sociograms, we opted for the „target sociogram” designed by M. L. Northway, which includes a system of concentric circles, in which the subjects are placed according to their popularity. The subjects' placement in these areas provided us with the possibility of both viewing how the pupils relate - over time - within the group, and highlighting those members who managed to draw, to the highest extent, the sympathy of a significant number of colleagues, occupying thereby the position of informal group leader (David, 2004, p. 147).

With a view to evaluating the skills formed in pupils, by means of the teaching activity, at the discipline Physical Education, in terms of development 
of personality features, we conceived groups of „skills to assess”, which we obtained by making operational the specific skills in the curriculum, according to a methodology adapted from the "Evaluation Guide - Humanities and Social Sciences” (Stoica and co. 2007, ID Proiect 3074).

The assessment moments (stages), by means of specific sociological questionnaires, as well as the sheet-fill-in, in order to determine the gains in terms of evolution of personality features, were marked, for orientation purposes, at the level of the annual thematic planes for the initial testing $\left(\mathrm{Ti}, 9^{\text {th }}\right.$ grade, $1^{\text {st }}$ semester), of the intermediate testing 1 and 2 (TI1;TI2, $9^{\text {th }}$ grade, $2^{\text {nd }}$ semester, and $10^{\text {th }}$ grade, $1^{\text {st }}$ semester), as well as for the final testing (TF), $10^{\text {th }}$ grade, $2^{\text {nd }}$ semester)

\section{Results and Discussions}

Analysis of the social networks extracted from the data collected at „Andrei Şaguna” National College, experimental class.

At the end of the initial testing applied to the experimental class $\left(9^{\text {th }}\right.$ grade) at the values afferent to the preferential-status indices, there are 8 subjects who have ,accepted” status, 3 with value of ,indifferent”, and 19 „marginalized". Out of the collective sociogram of the choices and the one of the rejections, a series of social networks ensue, which we will use in correlation with the implementation of the specific means (categories of motor skill games) in the lesson. The identification and the constitution of the social networks, as well as their use are the teacher's responsibility, since (s)he can notice, lesson by lesson, the evolution of each subject's social behaviour, and can change - in a positive sense - the structure of the networks.

After the intermediate testing 1 , one can see that, although the subjects' preferential status did not significantly change, the value of this index positively evolved (from -0,172 to -0,137 - the minimal values recorded for the preferentialstatus index at the end of the two tests). Therefore, the teacher could pass to the extension of the constituted social networks, with the informal group leader's aid and with two colleagues of the latter, with whom (s) he is in a relation of mutual attraction; these three pupils being considered binders of the newly formed group, who will act so as to improve the relations with some subjects, respectively to draw them from the indifference and marginalization area.

After the intermediate testing 2, and the calculation of the values afferent to the preferential-status index, the number of the subjects remained in the marginalization area of the class, significantly diminished to 3 subjects, with the minimal value of $-0,064$. Due to this result, the teacher had the opportunity to extend the previously created social networks, also with other subjects' aid, as "binders" of the group. The social network submitted in figure 1 was obtained, which consists in 2/3 of the experimental class members. 


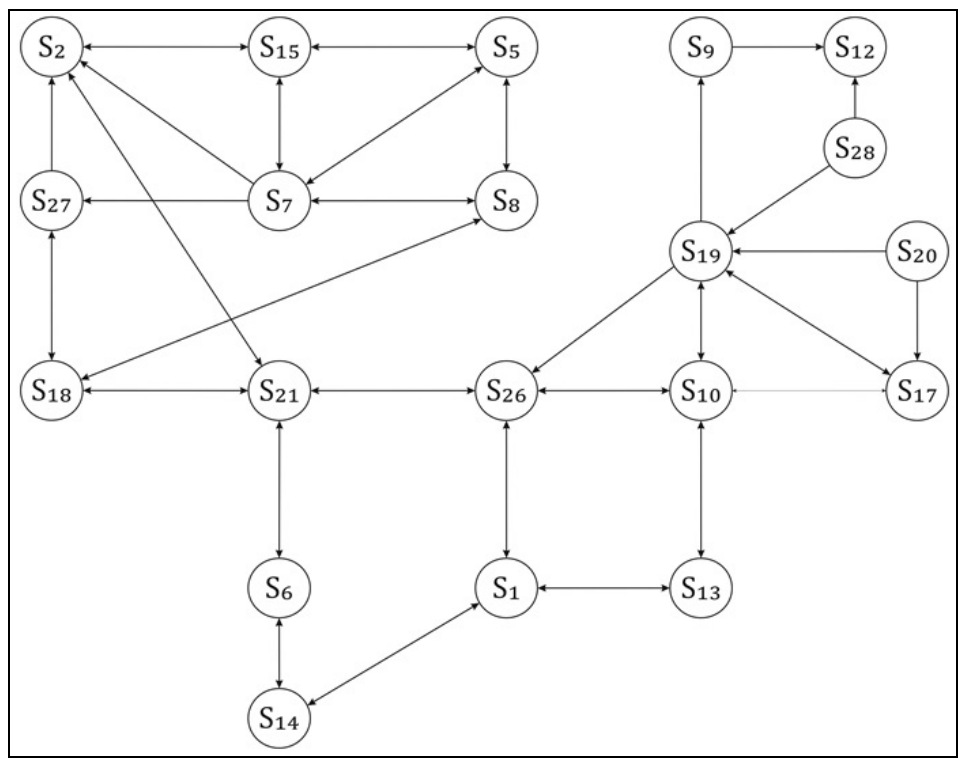

Figure 1. Social network extracted after the intermediate testing 2, in the experimental class $\left(10^{\text {th }}\right.$ class E), within „Andrei Şaguna” National College

By late $2^{\text {nd }}$ semester of the $10^{\text {th }}$ grade (experimental class), school year 2012 - 2013, in the final investigation stage, the centralized results of the sociometric questionnaire, displayed in the collective sociogram of the choices (Fig. 2), as well as in the one of the rejections (Fig. 3), show that, in the indifference and marginalization areas, only 5 subjects are left (1 indifferent; 4 rejected), as against the initial 22; and that, in the popularity area, 8 subjects entered, although in the initial investigation phase, neither of them had obtained the minimal value of the preferential-status index necessary for the access therein (Isp > 0,2).

As regards the control class $\left(10^{\text {th }}\right.$ grade), who covered traditional learning contents, at the end of the research, the data of the sociometric questionnaire, display at the sociogram of the choices (Fig. 4), respectively of the rejections (Fig. 5), the following configuration: 18 subjects are in the marginalization area, 4 are in the indifference area, and only 8 subjects - less than 1/3 of the entire class - are in the acceptance area.

This implies that the teaching methodology we implemented in the experimental class led to group members' tendency to focus towards the central area of the overall network. 


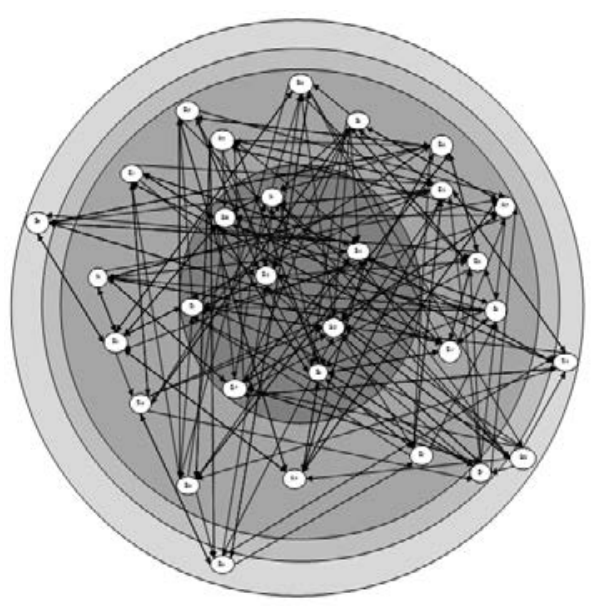

Figure 2. Collective sociogram of the choices at the final testing of the experimental group/class

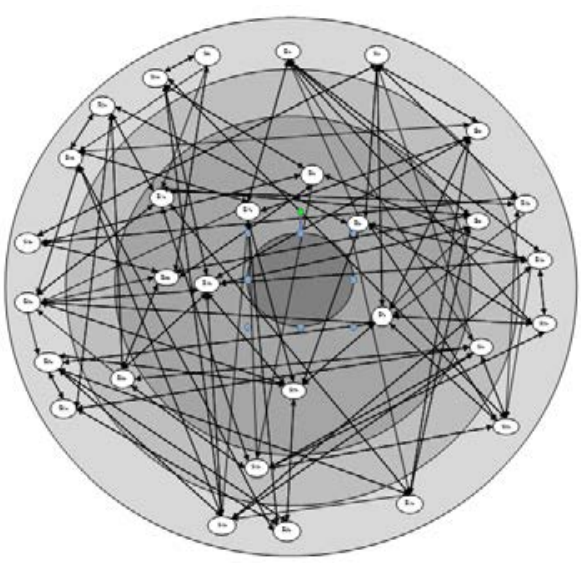

Figure 4. Collective sociogram of the choices at the final testing of the control group/class

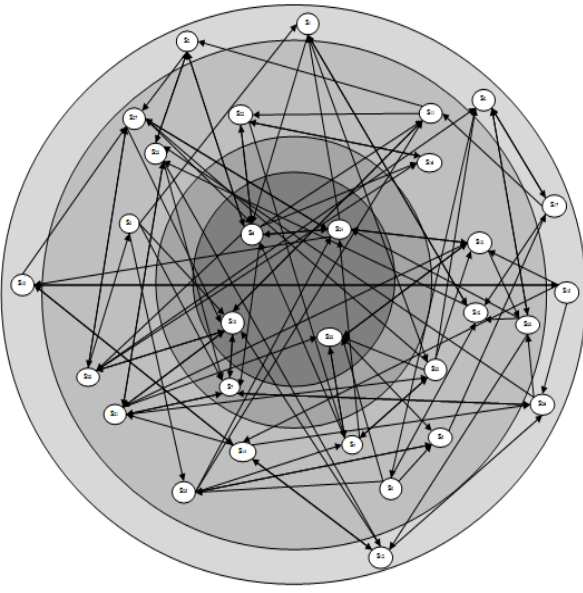

Figure 3. Collective sociogram of the rejections at the final testing of the experimental group/class

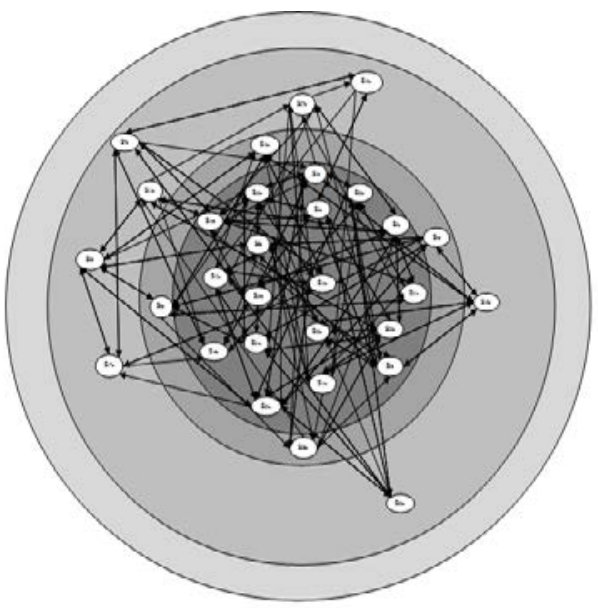

Figure 5. Collective sociogram of the rejections at the final testing of the control group/class

The briefly presented data, in terms of identification and operation - by the means encompassed in the methodology we devised - on certain specific social networks, extracted from the sociograms of the experimental class, show success in the improvement of the interpersonal group relations and, implicitly, in the improvement of the social behaviour of the respective class, which confirms - in this regard - the research hypothesis.

Assessment results as regards the skills acquired in line with the learning units nominated at the content "Development of personality traits". 
For each learning unit (see the planning documents for the discipline Physical Education, 2011) which target the content „Development of Personality Traits”, respectively: „Practical activities with specificity of leadership, subordination, collaboration”; „Conflicting situations likely to arise in practical activities” and „Ways to prevent/ settle/ solve conflicting situations”; „Behaviours integrated in the notion of fairplay”; „Regulations of sports disciplines" and, depending on the subordinated specific skills (Curriculum, 2009), several „skills to assess” were conceived; and, distinctly for each of them, descriptors/criteria for assessing the pupils' behaviour, based on: specification of the standard behaviour which must be proven; conditions in which the behaviour can either occur or become visible, measurable, assessable; performance, by enunciating a directly measurable success criterion - expressed by levels of knowledge, practical application, motor expression (Stoica et al., 2007, 2013; Mijaică, 2014).

The procedures and data collected in the assessment moments (initial, intermediary 1-2, final), were performed on/for each pupil, by means of individual assessment sheets, both in experimental and control classes. On the same sheet template, the average scores/class/targeted learning unit/skill to assess, obtained in all testing stages, were centralized (Tab. 2).

Table 2 Average scores cumulated for all learning units stipulated at the content „Development of Personality traits”, in both experimental and control classes, within „Andrei Şaguna” National College of Braşov

\begin{tabular}{|c|c|c|c|c|c|c|c|c|}
\hline $\begin{array}{l}\text { Development of } \\
\text { personality traits }\end{array}$ & \multicolumn{8}{|c|}{$\begin{array}{c}1^{\text {st }}-2^{\text {nd }} \text { Stages }-9^{\mathrm{TH}} \text { Grade B - Andrei Şaguna National College } \\
2^{\text {nd }} \text { Semester; school year } 2011-2012\end{array}$} \\
\hline $\begin{array}{l}\text { Learning units set out } \\
\text { in the annual scaling } \\
\text { chart }\end{array}$ & \multicolumn{2}{|c|}{$\begin{array}{c}\text { Practical } \\
\text { activities with } \\
\text { leadership, } \\
\text { subordina- } \\
\text { tion, } \\
\text { collaboration } \\
\text { specificity }\end{array}$} & \multicolumn{2}{|c|}{$\begin{array}{l}\text { Conflicting } \\
\text { situations that may } \\
\text { arise within } \\
\text { practical activities } \\
\text { and Modes of } \\
\text { preventing / settling } \\
\text { / solving the } \\
\text { conflicting situation }\end{array}$} & \multicolumn{2}{|c|}{$\begin{array}{l}\text { Behaviours } \\
\text { integrated in } \\
\text { the notion of } \\
\text { fair-play }\end{array}$} & \multicolumn{2}{|c|}{$\begin{array}{l}\text { Regulations } \\
\text { of sports } \\
\text { disciplines }\end{array}$} \\
\hline Assessment moments & $\mathrm{Ti}$ & $\mathrm{TI}_{1}$ & $\mathrm{Ti}$ & $\mathrm{TI}_{1}$ & $\mathrm{Ti}$ & $\mathrm{TI}_{1}$ & $\mathrm{Ti}$ & $\mathrm{TI}_{1}$ \\
\hline $\begin{array}{l}\text { Class-average score } \\
\text { (experimental class) }\end{array}$ & 1,96 & 3 & 1,74 & 2,78 & 1,57 & 2,5 & 1,92 & 2,83 \\
\hline $\begin{array}{l}\text { Class-average score } \\
\text { (control class) }\end{array}$ & 1,79 & 2 & 1,75 & 1,99 & 1,59 & 1,72 & 1,94 & 2,08 \\
\hline & \multicolumn{8}{|c|}{$\begin{array}{c}3^{\text {rd }}-4^{\text {th }} \text { Stages }-10^{\text {th }} \text { Grade B - Andrei Şaguna National College } 1^{\text {st }}- \\
2^{\text {nd }} \text { Semesters; school year } 2012-2013\end{array}$} \\
\hline Assessment moments & $\mathrm{TI}_{2}$ & Tf & $\mathrm{TI}_{2}$ & $\mathrm{Tf}$ & $\mathrm{TI}_{2}$ & $\mathrm{Tf}$ & $\mathrm{TI}_{2}$ & $\mathrm{Tf}$ \\
\hline $\begin{array}{l}\text { Class-average score } \\
\text { (experimental class) }\end{array}$ & 3,4 & 4,5 & 3,06 & 4,48 & 3 & 3,92 & 3,6 & 4,51 \\
\hline $\begin{array}{l}\text { Class-average score } \\
\text { (control class) }\end{array}$ & 2,2 & 2,7 & 2,29 & 2,77 & 1,79 & 1,93 & 2,36 & 2,77 \\
\hline
\end{tabular}

$\mathrm{Ti}$ - initial testing 
$\mathrm{TI}_{1}$ - intermediary testing 1

$\mathrm{TI}_{2}$ - intermediary testing 2

Tf - final testing

After calculating the signification of the difference between averages, upon evaluating the skills of the 4 learning units, the following were obtained:

- For the experimental class, the calculated $\mathrm{t}$ is of 15,87 , and for $\mathrm{f}=\mathrm{n}-1=$ $4-1=3$ degrees of liberty, and a probability of 0,99 (threshold of 0,01 ) there corresponds $\mathrm{t}=5,841$ (Table of Fischer - Novac, 1995, p.138); hence the difference between the value of the calculated $t$ and the one within the table, is significant.

- For the control class, the calculated $\mathrm{t}$ is of 2,58, and for $\mathrm{f}=\mathrm{n}-1=4-1=$ 3 degrees of liberty, and a probability of 0,99 (threshold of 0,01 ) there corresponds $t=5,841$, hence the difference between the value of the calculated $t$ and the one within the table, is insignificant.

According to the aforementioned data, we can state that, in the case of our research, the null hypothesis shall be rejected and the working hypothesis shall be accepted - in which case the experimentally applied teaching methodology determined, with a probability of 99\%, the pupils' gaining knowledge, skills, attitudes and actions, manifested in the field of interest allotted to personality features.

Data analysis in terms of the value and dynamics afferent to groupcohesion, in both experimental and control classes.

Acting on the social networks and personality traits of the pupils encompassed in the experimental class, as well as sociometrically investigating the control class, which, throughout the research, participated in traditional physical-education lessons, highlighted the dynamics of the cohesion index for the two groups.

The obtained values/assessment stages are shown in Tab. 3.

Table 3 Values of the cohesion coefficient/stages, resulted for both experimental and control classes within „Andrei Şaguna” National College - Braşov

\begin{tabular}{|l|c|c|}
\hline Intervention stage & $\begin{array}{c}\text { Value of the cohesion } \\
\text { coefficient for the } \\
\text { experimental group }\end{array}$ & $\begin{array}{c}\text { Value of the cohesion } \\
\text { coefficient for the } \\
\text { control group }\end{array}$ \\
\hline Initial stage & 0,023 & 0,021 \\
\hline Intermediate stage 1 & 0,225 & 0,108 \\
\hline Intermediate stage 2 & 0,531 & 0,203 \\
\hline Final stage & 0,603 & 0,316 \\
\hline
\end{tabular}

The comparison between the results obtained for the cohesion index of the group after the intial testing, shows that both classes display a weak cohesion, the coefficient having a value below 0,21 (according to the tabular values of Matei, 1981). As follows, in the experimental class, along with the application of the methodology focused on experiential learning structures/units, consisting of motor skill games applied in various moments of the lesson, the value of the cohesion 
index marked - from one stage to another - a progressive rise, the respective group pf pupils reaching - eventually - a significant level of cohesion (Tab. 3).

We cannot say the same thing about the control class, on which no intervention was made during the instructive - educative process, by specific acts (see the independent variable), its cohesion index only reaching a low level, its values not going over the threshold of 0,4 (Table 3).

The graphical representations for the progression of the obtained values, in both experimental and control classes are shown in figure 6 . As one can see, the value increase of the resulted cohesion coefficients/stage in the experimental class, display a far superior rising in relation to the control class, where the traditional physical and sports contents were covered. This leads us to say that the means consisting in various categories of motor skill games, selected and adapted to the formal instruction environment, as well as the application of a specific methodology for their implementation, within the teaching-learningevaluation act, determined, in correlation with the improvement of the social networks and with the improvement of the pupils' personality traits, a significant cohesion increase, in the experimental class.

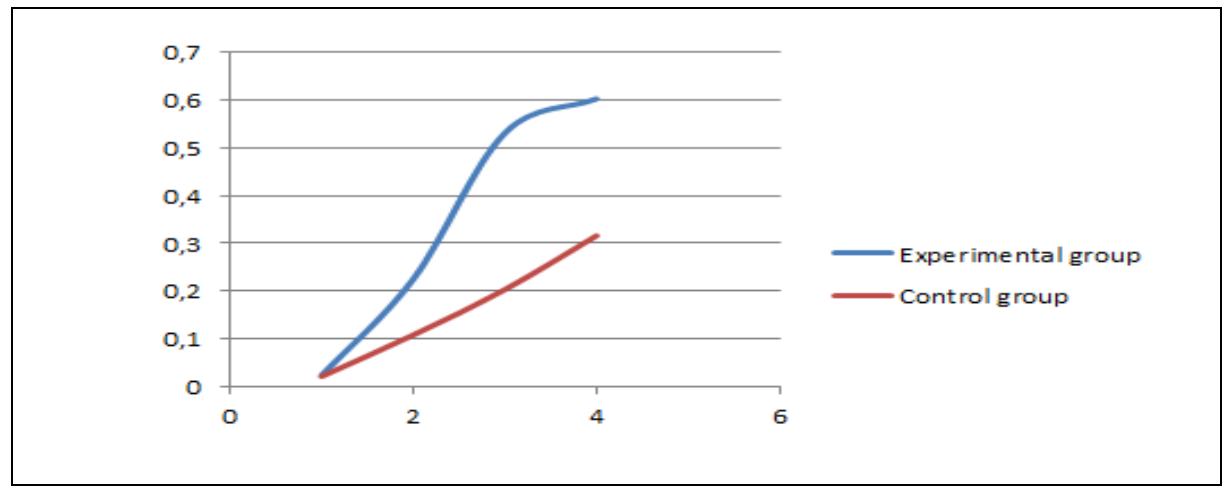

Figure 6. Dynamics of group cohesion for both experimental and control classes within „Andrei Şaguna” National College of Braşov

\section{Conclusions}

In line with Sullivan (quoted by Stoetzel, 1963, pp. 222-223) we dare say that, at individual level, there are positive or negative images about oneself and the others, lasting images, formed over time, as well as fluctuating, dynamic images, owed to momentary situations. The functioning of the interpersonal relations depends not only on making available either of these extant systems of images, but also on the nature of the combinations between them. In the case of our research, these combinations are given by the differentiated valences of the six categories of motor skill games, of the specific methodology for their enactment in the preimpact, impact, postimpact/revision stages.

The social networks within a class develop progressively, based on their ongoing evaluation, on the identification, by the teacher, of the pupils, respectively of the dyads, triads, etc., which may attract as many members as 
possible, in responsible collaboration and cooperation actions, in order to achieve the common goal given by the completion of each game.

The research data confirm that there is a relation of direct proportionality between the presence of positive personality traits, and a group's chance to reach a high cohesion level. Within the experimental group, where we noticed, gradually, that the roles were understood and undertaken, the pupils started to benefit from a high status, the leaders manifested their responsibility, and the cohesiveness tended to be high. In line with this observation, we recommend the pupils' involvement in conceiving, organizing and developing collective activities, with scenarios underlain by human motility; offering thereby as many opportunities of authentic, not fake, not constrained exteriorising of the personality traits, of the conceptions and attitudes either already acquired or in formation

The experimental activity has proven that improving the interpersonal relations and developing the personality traits determined a higher cohesion inthe class of pupils, a fact which we achived by our covering, with the pupils, several formal motor skill activities, other than those presented in the section (traditional) "learning contents" within the specialized curriculum - in force for the discipline Physical Education (2009), by selecting and adapting several categories of motor skill activities - motor skill games - which originate in contemporary nonformal education.

\section{References}

1. BASILIADE, G. (1976). Socializare, integrare şi comportament deviant. Bucureşti: Centrul de cercetări pentru problemele tineretului, 227;

2. BOGATHY, Z. (2004). Manual de Psihologia Muncii şi Organizaţională, Iaşi: POLIROM, 255;

3. COHEN, E. (1994). Restructuring the classroom: Conditions for productive small groups, Review of Educational Research 64, 1-35;

4. DAVID, E. (2004). Sociologie, Sibiu: PSIHOMEDIA,147;

5. DRAGNEA, A., şi colab, (2000). Teoria educaţiei fizice şi sportului, Bucureşti: CARTEA ŞCOLII, 56;

6. EPURAN, M. (2005). Metodologia cercetării activităţilor corporale, Bucureşti: FEST, 255-256;

7. GOLU, M. (2002). Bazele psihologiei generale, Bucureşti: Editura UNIVERSITARĂ, 124;

8. MARICA S. (2008). Introducere în psihologia socială, Bucureşti: FUNDAŢIA ROMÂNIA DE MÂINE, 106;

9. MATEI, C. (1981). Psihologia relaţiilor morale interpersonale - studii de antropologie psihologică, Craiova: SCRISUL ROMÂNESC, 108;

10. NOVAC, A. (1995), Statistică socială aplicată, Bucureşti: HYPERION XXI, 113-138;

11. SHAW, S.M. (1997). Controversies and contradictions in family leisure: An analysis of conflicting paradigms. Journal of Leisure Research, 29 (1), 98 112 ; 
12. SHAW, S.M. (2000). Ideals versus reality: Contradictory aspects of family leisure. In D. Samdahl, M. Havits (Eds.), Abstract of the proceedings of the 2000 NRPA Leisure Research Symposium (p. 56). Alexandria. VA: National Recreation and Park Association;

13. SHERIF C. (1976). Social Problems in athletics, Champaingn, IL: University of Illinois Press., p. 108;

14. STOETZEL, J. (1963). La psychologie sociale, Paris: FLAMMARION, 222-223;

15. STOICA şi colab., Ghid de evaluare - discipline socio-umane, 2007 2013

https://insam.softwin.ro/fisiere/GHID\%20DE\%20EVAL_SOCIO_UMAN E2.pdf ;

16. *** Programa de Educaţie fizică, 2009.

\title{
OPTIMIZAREA COEZIUNII DE GRUP PRIN RESTRUCTURAREA RETTELELOR SOCIALE UTILIZÂND J OCURILE MOTRICE ÎN LECȚIA DE EDUCAȚIE FIZICĂ
}

\author{
Mijaică Raluca ${ }^{1}$ \\ ¿Universitatea „Transilvania” din Brașov, Bulevardul Eroilor nr. 29, 500036 România
}

Cuvinte cheie: lecția de educație fizică, jocuri motrice, coeziunea clasei

\section{Rezumat}

Clasa de elevi posedă toate caracteristicile specifice unui grup social primar, iar grupurile cu coeziune ridicată, se consideră că sunt capabile să-şi stabilească mai uşor standarde de performanţă. Premisa studiului nostru experimental, a pornit de la convingerea că educaţia fizică este una dintre disciplinele care ar putea contribui substanţial la dezvoltarea personală şi socială a elevilor. Experimentul pe care l-am realizat, a constat din implementarea în cadrul lecțiilor de educație fizică a unui set de 6 categorii de jocuri motrice, aplicat la nivelul claselor IX-X pe durata a trei semestre, $\mathrm{cu}$ scopul de a ameliora coeziunea grupului, relațiile interpersonale și trăsăturile de personalitate a elevilor participanți. Datele cercetării au pus în evidență gradul de eficiență a demersului nostru didactic, conducând la concluzia că, creşterea coeziunii clasei de elevi, ameliorarea relaţiilor interpersonale şi dezvoltarea trăsăturilor de personalitate, se poate realiza prin preluarea adecvată a unor categorii de activităţi motrice - jocuri, cu origine în educaţia nonformală.

\section{Introducere}

Grupul social mic este caracterizat prin existenţa unui anumit număr de persoane, a unui scop comun către care sunt orientate eforturile membrilor grupului, a unei reţele de status (poziţia de bază a individului în societate), 
(Lindsey, citat în Golu, 2002, p. 124), a unui sistem de norme şi valori recunoscute şi acceptate de membri, care le reglează acestora conduita, în conformitate cu interesele grupului.

Clasa de elevi este un grup de muncă specific, compus dintr-un număr de membri egali între ei (elevii) şi dintr-un animator (profesorul). În cadrul ei coexistă o sumă de raporturi, ce sunt reglementate oficial, de tipul sarcinii şi a normelor de funcţionare date. La nivelul clasei, odată cu transformarea ei într-un grup social, fiecare elev dobândește un status, pozitiv, negativ sau nul, ceea ce indică existenţa unor subiecţi populari, acceptaţi, indiferenţi sau marginalizaţi (izolaţi afectiv) în cadrul grupului (Bogáthy, 2004, p. 255). Acest status prezintă o dezvoltare și de cele mai multe ori, o restructurare, în funcție de modul de implicare personală a fiecărui membru, în realizarea obiectivelor impuse și neimpuse pe care clasa de elevi le urmărește.

Fiecare clasă de elevi, se caracterizează printr-un anumit nivel de coeziune. Coeziunea exprimă atracţia globală pe care grupul o exercită asupra membrilor săi, prin intermediul funcţiei de control, a presiunii spre uniformitate şi a integrării afective a membrilor, ceea ce are drept rezultat formarea sentimentului de „noi”, care prevalează asupra tendinţelor de autonomie individuală (Marica, 2008, p. 106). Coeziunea este rezultatul acţiunii unor variate categorii de factori, ce țin de nevoile fundamentale ale individului: de integrare, afirmare sau recunoaştere socială, trebuinţele de afecţiune, comunicare sau protecţie, cele de ascendenţă sau dependenţă etc. și toate acestea configuraţii motivaţionale specifice fiecărei persoane, pot fi satisfăcute în mod diferenţiat, într-o măsură care depinde de calităţile structurale şi funcţionale ale grupului, ca sistem.

Grupurile cu coeziune ridicată sunt capabile să-şi stabilească mai uşor standarde de performanţă şi pot oferi o gamă mai largă de recompense membrilor săi. Shaw (1997, pp. 98-112; 2000, p. 56) a demonstrat că, grupurile înalt coezive sunt cooperante şi prietenoase, folosind o formă democratică de control al comportamentului. Dimpotrivă, în grupurile cu coeziune redusă, același autor a constatat că membrii ce o compun, erau ostili şi agresivi unii cu ceilalţi, încântaţi când colegii lor făceau greşeli, iar stilul de luare a deciziilor era unul autocratic. De asemenea, Sheriff (1976, p. 108) a constatat că, competiţia intergrup poate însemna o practică de ridicare a normelor generale. Cohen (1994, pp. 1- 35), a observat că în unele situaţii, coeziunea grupului poate interfera cu caracterul de analiză şi examinare al informaţiei, iar membrii grupurilor coezive sunt adesea potrivnici contribuţiilor altor membrii din afara grupului.

Pentru a putea crește coeziunea unui grup, acțiune în care se înscrie și cercetarea noastră, membrii acestuia trebuie supuși unei acțiuni de socializare. Prin socializare înțelegem parcurgerea unui proces de interiorizare a normelor, principiilor şi valorilor, însuşirea regulilor sociale etc., fapt posibil prin actul de învățare motrică, știut fiind faptul că, una dintre funcțiile asociate ale educației fizice școlare, este aceea de socializare Dragnea, (2000, p.56), respectiv de asimilarea a normelor şi valorilor sociale. 


\section{Material și metode}

Premisa principală a cercetării de față își are originea în faptul că, educația fizică este parte integrantă a conceptului de educație, iar acțiunea de socializare se constituie într-o premisă favorabilă a activităţilor educaţionale în general. Între educaţie şi socializare se instituie raporturi permanente de intercondiţionare şi complementaritate funcţională, iar funcţiile şi scopurile educaţiei - implicit și cele ale educației fizice - se manifestă ca mijloace de integrare socială a indivizilor şi de participare a lor în sistemul relaţiilor sociale (Basiliade, 1976, p. 227).

Ipoteza de la care am pornit în această cercetare constă în faptul că, ameliorarea relaţiilor interpersonale de la nivelul clasei de elevi, precum și dezvoltarea trăsăturilor de personalitate la membrii componenți prin parcurgerea în cadrul lecțiilor de educaţie fizică a unor activităţi specifice de joc multivalent din perspectivă educațională, determină în mod semnificativ ameliorarea coeziunii clasei.

Tabel 1 Centralizator al duratei de timp alocată categoriilor de jocuri motrice în lecțiile de educație fizică, pe perioada integrală a cercetării

\begin{tabular}{|c|c|c|c|c|c|}
\hline \multirow{4}{*}{ No. } & \multirow{4}{*}{$\begin{array}{c}\text { Categorii de } \\
\text { jocuri } \\
\text { nonformale }\end{array}$} & \multicolumn{4}{|c|}{ Clasa experimentală } \\
\hline & & \multicolumn{2}{|c|}{$\begin{array}{c}\text { Clasa a IX-a / Anul școlar } \\
2011-2012\end{array}$} & \multicolumn{2}{|c|}{$\begin{array}{c}\text { Clasa a IX-a / Anul școlar } 2012 \text { - } \\
2013\end{array}$} \\
\hline & & Semestrul I & Semestrul II & Semestrul I & Semestrul II \\
\hline & & 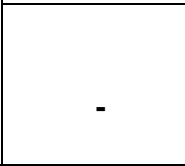 & $\begin{array}{c}\text { Numărul } \\
\text { structurilor } \\
\text { experiențiale/mi } \\
\text { n/ore alocate }\end{array}$ & $\begin{array}{c}\text { Numărul } \\
\text { structurilor } \\
\text { experiențiale/mi } \\
\text { n/ore alocate } \\
\end{array}$ & $\begin{array}{c}\text { Numărul } \\
\text { structurilor } \\
\text { experiențiale/mi } \\
\text { n/ore alocate }\end{array}$ \\
\hline 1 & $\begin{array}{l}\text { Jocuri de } \\
\text { cunoaștere a } \\
\text { membrilor din } \\
\text { grup }\end{array}$ & \multirow{6}{*}{ 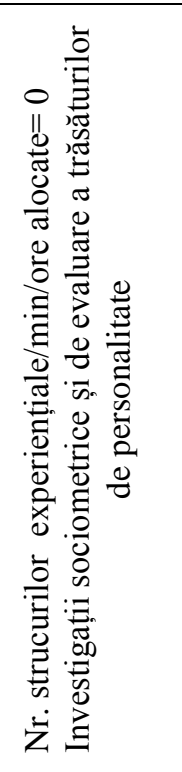 } & 6/ 60min / 1oră & $2 / 15 \mathrm{~min}$ & \\
\hline 2 & $\begin{array}{l}\text { Jocuri de } \\
\text { contact fizic }\end{array}$ & & $7 / 70 \mathrm{~min} / 1: 10$ & $4 / 40 \mathrm{~min}$ & 8 / 80min / 1:20 \\
\hline 3 & $\begin{array}{l}\text { Jocuri de } \\
\text { încredere }\end{array}$ & & 9 / 90min / 1:30 & 6/60min / 1oră & $\begin{array}{l}\text { 11 / 110min / } \\
1: 50\end{array}$ \\
\hline 4 & $\begin{array}{l}\text { Jocuri de } \\
\text { construire a } \\
\text { activităților în } \\
\text { echipă }\end{array}$ & & 6 / 60min / 1oră & $7 / 70 \mathrm{~min} / 1: 10$ & $7 / 70 \mathrm{~min} / 1: 10$ \\
\hline 5 & $\begin{array}{l}\text { Jocuri care } \\
\text { dezvoltă } \\
\text { cominicarea și } \\
\text { cooperarea }\end{array}$ & & 9 / 90min / 1:30 & 6 / 60min / 1 oră & $\begin{array}{l}15 / 150 \mathrm{~min} / \\
2: 30\end{array}$ \\
\hline \multirow[t]{2}{*}{6} & $\begin{array}{l}\text { Jocuri de } \\
\text { protejare a } \\
\text { mediului }\end{array}$ & & $\begin{array}{c}2 / 15 \mathrm{~min}+ \\
1 \text { activitate / } \\
120 \mathrm{~min} / 2 \text { ore }\end{array}$ & - & \begin{tabular}{l}
\multicolumn{1}{c}{$1 / 10 \mathrm{~min}+$} \\
1 activitate / \\
$120 \mathrm{~min} / 2$ ore
\end{tabular} \\
\hline & & - & $\begin{array}{l}39+1 \text { activitate } \\
=8 \text { ore și } 10 \mathrm{~min}\end{array}$ & $\begin{array}{l}25=4 \text { ore și } 5 \\
\min \end{array}$ & $\begin{array}{l}42+1 \text { activitate } \\
=8 \text { ore și } 50 \mathrm{~min}\end{array}$ \\
\hline \multicolumn{2}{|c|}{ Totalul orelor alocate } & \multicolumn{4}{|c|}{ 21ore și $5 \mathrm{~min}$} \\
\hline
\end{tabular}


Pentru metodologia implementată experimental, s-a conceput o strategie didactică de programare/eșalonare a unor unități/structuri de învățare motrică experiențială, cu conținuturi ce cuprind 6 categorii de jocuri (tabelul 1), cu un total de 112 jocuri de bază, la care s-au adăugat diferite variante de exersare ale acestora (în funcție de obiectivul operațional urmărit, complexitatea activității, durata, locul de desfășurare, nivelul de risc etc.). Jocurile au fost aplicate la nivelul unei clase experimentale, lecție de lecție, pe durata a doi ani de studii, respectiv pe întinderea a trei semestre. Cumulativ, ca durată de timp afectată acestor activități, am consumat din cadrul lecțiilor, timpii prezentați în Tab. 1.

Experimentul pe care l-am realizat, a fost de tip pre-test - post-test (sau model de „serie întreruptă, cu grupe de control, cu grupe neechivalente”, după Epuran, 2005, p. 255 - 256), urmând schema:

Grupa experimentală test 1 V.I. test 2 V.I. test 3

Grupa de control test 1 - test 2 - test 3

(unde V.I. este variabila independentă a experimentului, respectiv metodologia constând din paleta de jocuri implementate în lecțiile de educație fizică și se compară comportamentul celor două grupe)

Ca subiecți ai cercetării, pe orizontală ca palier de şcolarizare, am optat pentru implementarea metodologiei concepute, la nivelul claselor a IX-a, (30 de elevi la clasa experimentală și 30 de elevi la clasa de control), clase selecţionate în anul şcolar 2011-2012 (cu mențiunea că, începutul experimentului propriu-zis a demarat în semestrul al II-lea a anului școlar, după ce subiecții s-au acomodat cu noul mediu şcolar) şi continuarea demersului la aceleaşi clase, respectiv subiecţi, care au parcurs anul şcolar 2012-2013, în clasele a X-a (semestrele I și II), la Colegiul Național „Andrei Șaguna” din Brașov.

Ca metodă de testare a relaţiilor interpersonale pentru clasele vizate, am apelat la metoda sociometrică (Matei, 1981, p. 108), Chestionarele (compuse din opt întrebări) au fost aplicate, atât membrilor clasei experimentale, cât şi celor din clasa de control. Rezultatele au fost prelucrate cu ajutorul tehnicii sociometrice şi centralizate prin întocmirea matricelor sociometrice (unde apar datele centralizate al numărului şi valorilor preferinţelor şi respingerilor obţinute). Pe baza acestora, s-a efectuat calculul indicelui de status sociometric (Iss) şi status preferenţial (Isp) al fiecărui subiect/etapă de evaluare. $\mathrm{Cu}$ aceste rezultate, s-a calculat coeficientul de coeziune (Cgr)/etapă al claselor experimentală și de control. De asemenea, datele centralizate în matricele sociometrice, au fost transpuse conform tehnicii sociometrice, în sociograme ale alegerilor şi respingerilor/etapă. Ele ne-au permis/etapă de evaluare, detectarea diadelor, triadelor, lanţurilor sau a altor tipuri de relaţii interpersonale, după caz. Ca formă de prezentare grafică a sociogramelor, am optat pentru ,sociogramaţintă" concepută de către M. L. Northway, care cuprinde un sistem de cercuri concentrice, în care subiecţii sunt dispuşi în funcţie de gradul de popularitate. Plasarea subiecţilor în aceste zone ne-a oferit, atât posibilitatea vizualizării modului în care elevii relaţionează - în timp - în cadrul grupului, cât şi evidenţierea acelor membri care au reuşit să atragă, în cea mai mare măsură, 
simpatia unui număr semnificativ de colegi, ocupând astfel, poziția de lider informal al grupului (David, 2004, p. 147).

Pentru evaluarea competenţelor formate la elevi prin activitatea didactică la disciplina Educaţie fizică, pe direcția dezvoltării trăsăturilor de personalitate, am conceput grupaje de „competenţe de evaluat”, pe care le-am obținut printrun proces de operaţionalizare a competenţelor specifice din programa şcolară, după o metodologie adaptată din ,Ghidul de evaluare - discipline socio-umane” (Stoica și colab. 2007, ID Proiect 3074).

Momentele (etapele) de evaluare prin intermediul chestionarelor sociologice specifice, precum şi cele de completare a fișelor pentru determinarea achizițiilor privind evoluția trăsăturilor de personalitate, au fost marcate orientativ la nivelul planurilor tematice anuale, pentru testarea iniţială (Ti, clasele a IX-a, semestul I), testările intermediare 1 şi 2 (TI1;TI2, clasele a IX-a semestrul II şi clasele a X-a semestrul I), cât şi pentru testarea finală (TF), la clasele a X-a, semestrul II)

\section{Rezultate și discuții}

Analiza reţelelor sociale extrase din datele recoltate la Colegiul Naţional „Andrei Şaguna”, clasa experimentală.

La finele testării iniţiale aplicată clasei experimentale (a IX-a) la valorile indicilor de status preferenţial se regăsesc 8 subiecţi ce au statut de ,acceptaţi”, 3 cu valoare de ,indiferenţi” şi 19 ,marginalizaţi”. Din sociograma colectivă a alegerilor şi cea a respingerilor, se desprind o serie de reţele sociale, pe care le vom utiliza în corelație cu implementarea mijloacele specifice (categorii de jocuri motrice) în lecție. Identificarea și constituirea reţelelor sociale, utilizarea lor intră în sarcina cadrului didactic, deoarece acesta poate observa, lecţie de lecţie, evoluţia comportamentului social al fiecărui subiect şi poate schimba - în sens pozitiv - structura reţelelor.

După testarea intermediară 1 , se poate observa că, deşi statutul preferenţial al subiecţilor nu s-a modificat semnificativ, valoarea acestui indice a evoluat în sens pozitiv (de la -0,172 la -0,137 - valorile minime înregistrate de indicele de status preferenţial la finele celor două testări). Ca atare, cadrul didactic a putut trece la extinderea reţelelor sociale formate, cu ajutorul liderului informal al grupului și cu alți doi colegi ai acestuia, cu care se află în relaţie de atracţie reciprocă, cei trei putând fi considerați ca lianţi al grupului nou format, care va acționa pentru a îmbunătăţi relaţiile cu unii subiecți, respectiv pentru atragerea lor din zona de indiferenţă şi marginalizare.

După testarea intermediară 2 şi calcularea valorilor indicelui de status preferenţial, numărul subiecţilor rămaşi în zona de marginalizare a clasei a scăzut semnificativ, la 3 subiecți, cu valoarea minimă de $-0,064$. Datorită acestui rezultat, cadrul didactic a a avut oportunitatea de a extinde rețelele sociale create anterior şi prin utilizarea altor subiecţi, ca „lianţi” ai grupului. S-a obţinut rețeaua socială prezentată în figura 1 , care este constituită din $2 / 3$ dintre membrii clasei experimentale. 


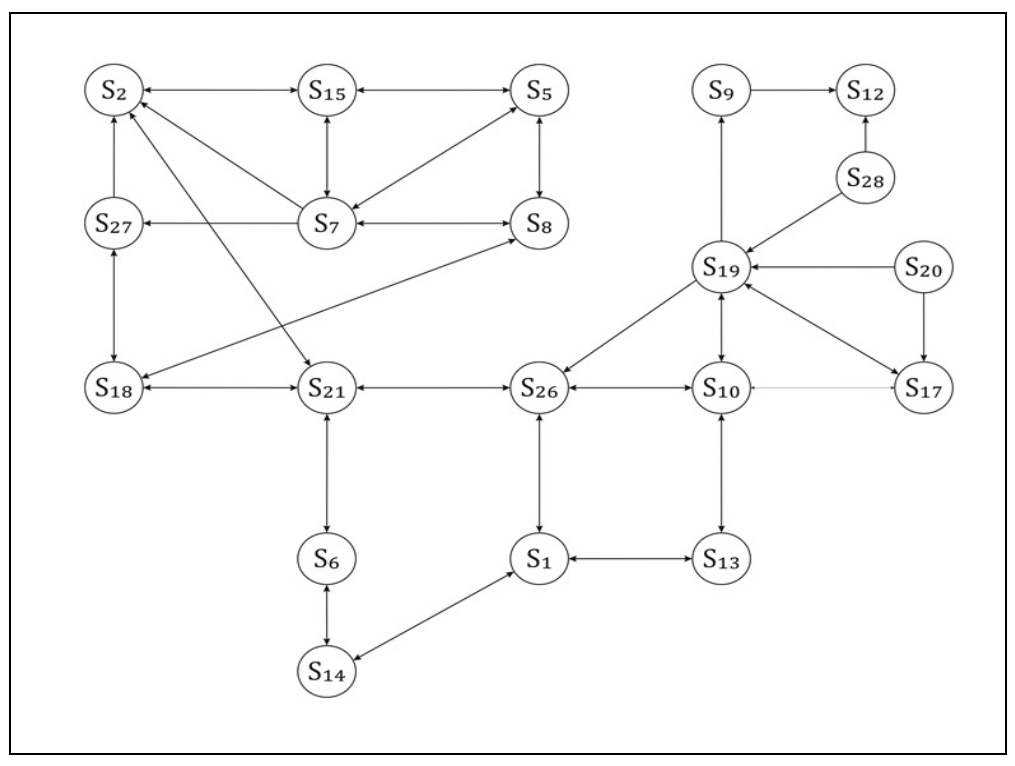

Figura 1. Reţea socială extrasă în urma testării intermediare 2, la clasa experimentală (XE), din cadrul Colegiului Naţional „Andrei Şaguna”

La finele semestrului II, al clasei a X-a (clasa experimentală), an şcolar 2012 - 2013, în etapa finală de investigare, rezultatele centralizate ale chestionarului sociometric, prezentate în sociograma colectivă a alegerilor (Fig. 2), precum şi în cea a respingerilor (Fig. 3), ne arată faptul că, în zona de indiferenţă şi cea de marginalizare au mai rămas doar 5 subiecţi (1 indiferent; 4 respinşi), faţă de cei 22 , câţi au fost iniţial, iar în zona popularităţii au intrat 8 subiecţi, deşi în etapa iniţială de investigare, niciunul nu obţinu-se valoarea minimă necesară a indicelui de status preferenţial necesar pentru accesul în această arie (Isp > 0,2). În ceea ce privește clasa de control (clasa a X-a), care a parcurs conținuturi de învățare tradiționale, la finalul cercetării, datele chestionarului sociometric, prezintă la sociograma alegerilor (Fig. 4), respectiv respingerilor (Fig.5), următoarea configurație: 18 subiecţi se află în zona de marginalizare, 4 sunt în cea de indiferenţă şi doar 8 subieci - mai puţin de $1 / 3$ din colectivul clasei - se situează în zona de acceptare. Acest lucru denotă faptul că, metodologia didactică pe care am implementat-o la nivelul clasei experimentale a dus la tendinţa de focalizare a membrilor grupului, spre zona centrală a rețelei luată pe ansamblu. 


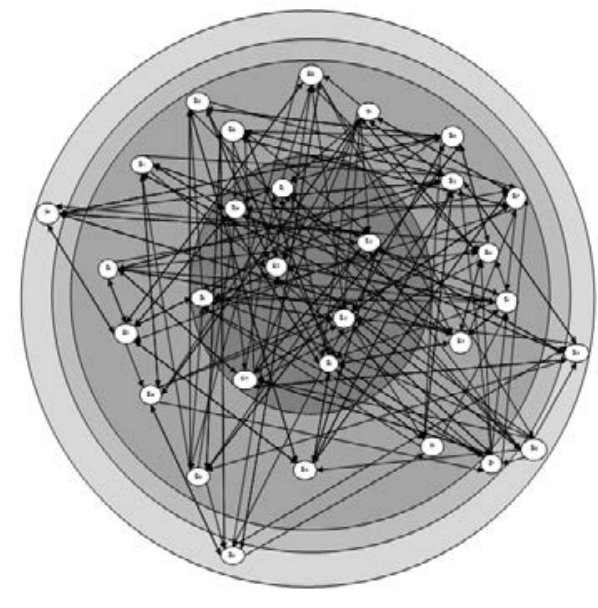

Figura 2. Sociograma colectivă a alegerilor la testarea finală a clasei/grupului experimental

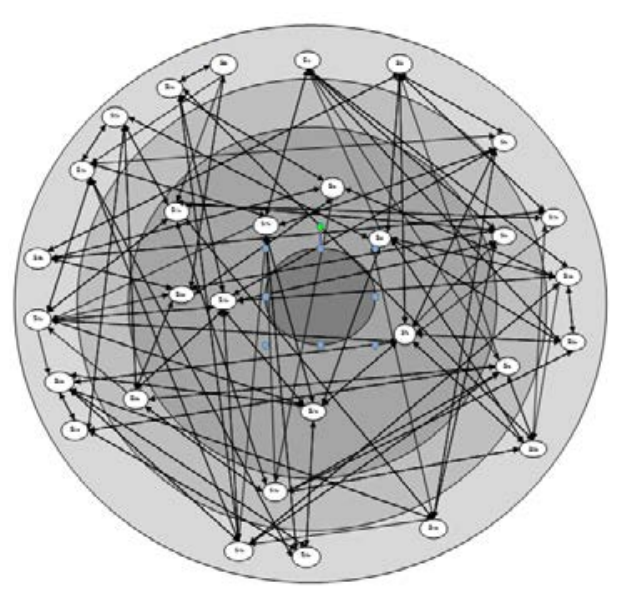

Figura 4. Sociograma colectivă a alegerilor la testarea finală a clasei/grupului de control

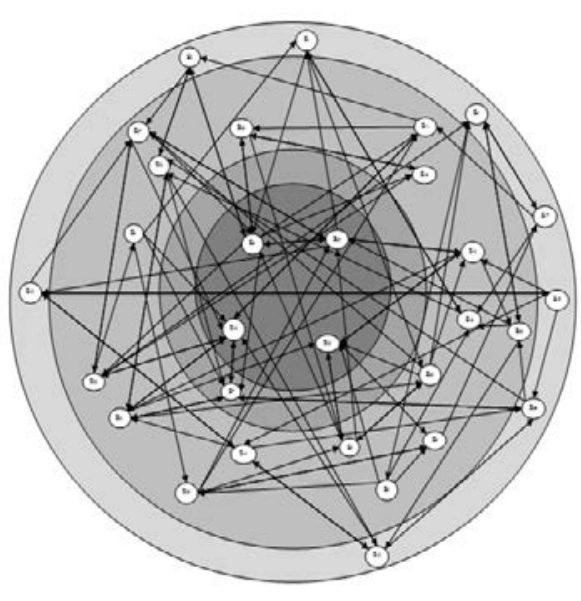

Figura 3. Sociograma colectivă a respingerilor la testarea finală a clasei/grupului experimental

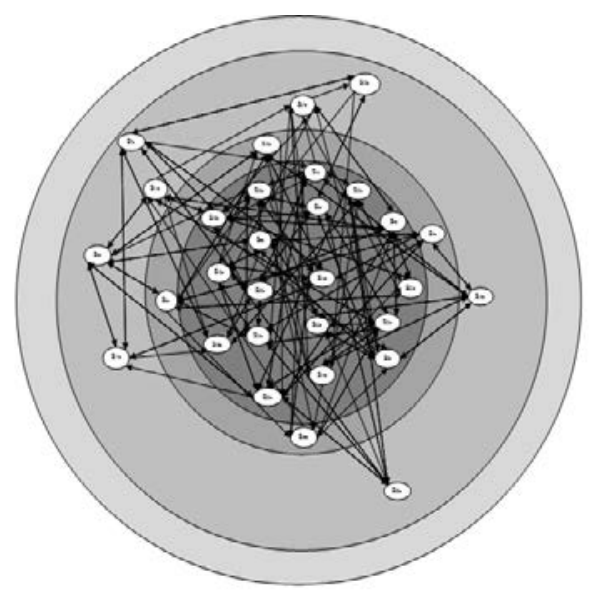

Figura 5. Sociograma colectivă a respingerilor la testarea finală a clasei/grupului de control

Din datele prezentate succint, privind identificarea şi acţionarea - prin mijloacele cuprinse în metodologia pe care am conceput-o - asupra unor anumite rețelele sociale, extrase din sociogramele clasei experimentale, s-a reuşit să se determine ameliorarea relaţiilor interpersonale de grup şi implicit, să se îmbunătăţească comportamentul social al clasei respective, ceea ce confirmă - pe această direcţie - ipoteza cercetării.

Rezultatele evaluării competenţelor achiziționate pe direcția unităţilor de învăţare nominalizate la conţinutul „Dezvoltarea trăsăturilor de personalitate”.

Pentru fiecare unitate de învăţare (vezi documentele de planificare la disciplina educație fizică, 2011) ce vizează conţinutul „Dezvoltarea trăsăturilor 
de personalitate”, respectiv: „Activităţi practice cu specific de conducere, subordonare, colaborare”; „Situaţii conflictuale care pot interveni în activităţile practice" şi „Modalităţi de prevenire/ aplanare/ rezolvare a situaţiilor conflictuale"; "Comportamentele integrate în noţiunea de fairplay"; „Regulamentele disciplinelor sportive" și dependent de competenţele specifice subordonate (Programa școlară, 2009), s-au conceput „competenţe de evaluat” şi în mod distinct pentru fiecare dintre acestea, descriptori/criterii de evaluare a comportamentului elevilor, având la bază: precizarea comportamentului etalon ce trebuie demonstrat; condiţiile în care se poate produce comportamentul sau în care acesta poate deveni vizibil, măsurabil, evaluabil; performanţa, prin enunţarea unui criteriu de reuşită direct măsurabil - exprimabil prin niveluri de cunoaştere, de aplicare practică, exprimare motrică (Stoica et al., 2007, 2013, Mijaică, 2014).

Procedurile şi datele recoltate la momentele de evaluare (iniţial, intermediar 1-2, final), au fost efectuate pe/pentru fiecare elev, prin intermediul unor fișe individuale de evaluare, atât la clasa experiemntală, cât şi la cea de control. Pe acelaşi model de fişe, s-a realizat centralizarea scorurilor medii/clasă/unitate de învăţare vizată/competenţă de evaluat, obţinute în toate etapele de testare (Tab. 2).

Tabelul 2. Scorurile medii cumulate pentru toate unităţile de învățare prevăzute la conţinutul „,Dezvoltarea trăsăturilor de personalitate”, la clasa experimentală şi de control din cadrul Colegiului Naţional „Andrei Şaguna” din Braşov

\begin{tabular}{|c|c|c|c|c|c|c|c|c|}
\hline $\begin{array}{l}\text { Dezvoltarea } \\
\text { trăsăturilor de } \\
\text { personalitate }\end{array}$ & \multicolumn{8}{|c|}{$\begin{array}{c}\text { Etapele I și II - Clasa a IX-a - Colegiul Național Andrei Şaguna } \\
\text { Semestrul II; Anul școlar } 2011 \text { - } 2012\end{array}$} \\
\hline $\begin{array}{l}\text { Unități de învățare } \\
\text { prevăzute în grafícul } \\
\text { anual de eșalonare }\end{array}$ & \multicolumn{2}{|c|}{$\begin{array}{c}\text { Activități } \\
\text { practice cu } \\
\text { specific de } \\
\text { conducere, } \\
\text { subordonare, } \\
\text { colaborare }\end{array}$} & \multicolumn{2}{|c|}{$\begin{array}{l}\text { Situații conflictuale } \\
\text { care pot interveni în } \\
\text { activitățile practice } \\
\text { /Modalități de } \\
\text { prevenire / aplanare } \\
\text { / rezolvare a } \\
\text { situațiilor } \\
\text { conflictuale } \\
\end{array}$} & \multicolumn{2}{|c|}{$\begin{array}{l}\text { Comportamen } \\
\text {-te integrate în } \\
\text { noțiunea de } \\
\text { fair-play }\end{array}$} & \multicolumn{2}{|c|}{$\begin{array}{l}\text { Regulamen- } \\
\text { tele } \\
\text { disciplinelor } \\
\text { sportive }\end{array}$} \\
\hline Momente de evaluare & $\mathbf{T i}$ & $\mathbf{T I}_{1}$ & $\mathbf{T i}$ & $\mathbf{T I}_{\mathbf{1}}$ & $\mathbf{T i}$ & $\mathbf{T I}_{\mathbf{1}}$ & $\mathbf{T i}$ & $\mathbf{T I}_{\mathbf{1}}$ \\
\hline $\begin{array}{l}\text { Scor media clasei } \\
\text { (clasa experimentală) }\end{array}$ & 1,96 & 3 & 1,74 & 2,78 & 1,57 & 2,5 & 1,92 & 2,83 \\
\hline $\begin{array}{l}\text { Scor media clasei } \\
\text { (clasa de control) }\end{array}$ & 1,79 & 2 & 1,75 & 1,99 & 1,59 & 1,72 & 1,94 & 2,08 \\
\hline & \multicolumn{8}{|c|}{$\begin{array}{c}\text { Etapele III-IV -Clasa a X-a-Colegiul Naţional Andrei Şaguna } \\
\text { Sem. I și II; Anul școlar 2012 - } 2013\end{array}$} \\
\hline Momente de evaluare & $\mathbf{T I}_{2}$ & Tf & $\mathbf{T I}_{2}$ & Tf & $\mathbf{T I}_{2}$ & Tf & $\mathbf{T I}_{2}$ & Tf \\
\hline $\begin{array}{l}\text { Scor media clasei } \\
\text { (clasa experimentală) }\end{array}$ & 3,4 & 4,5 & 3,06 & 4,48 & 3 & 3,92 & 3,6 & 4,51 \\
\hline $\begin{array}{l}\text { Scor media clasei } \\
\text { (clasa de control) }\end{array}$ & 2,2 & 2,7 & 2,29 & 2,77 & 1,79 & 1,93 & 2,36 & 2,77 \\
\hline
\end{tabular}

$\mathrm{Ti}$ - testare iniţială 
$\mathrm{TI}_{1}-$ testare intermediară 1

$\mathrm{TI}_{2}$ - testare intermediară 2

$\mathrm{Tf}$ - testare finală

În urma calculării semnificaţiei diferenţei dintre medii, la evaluarea competenţelor celor 4 unităţi de învăţare, s-au obținut următoarele:

- La clasa experimentală, $\mathrm{t}$-ul calculat este de 15,87, iar pentru $\mathrm{f}=\mathrm{n}-1=4-1=$ 3 grade de libertate şi o probabilitate de 0,99 (prag de 0,01 ) corespunde un $\mathrm{t}=$ 5,841 (Tabela lui Fischer - Novac, 1995, p.138), deci diferenţa dintre valoarea tului calculat și a celui tabelar este semnificativă.

- La clasa de control, t-ul calculat este de 2,58, iar pentru $\mathrm{f}=\mathrm{n}-1=4-1=3$ grade de libertate şi o probabilitate de 0,99 (prag de 0,01 ) corespunde un $t=$ 5,841, fapt ce ne demonstrează că diferenţa dintre valoarea t-ului calculat și a celui tabelar, este nesemnificativă.

Conform datelor menţionate, putem afirma că, în cazul cercetării noastre, se respinge ipoteza nulă și se acceptă ipoteza de lucru, conform căreia, metodologia didactică aplicată experimental a determinat, cu o probabilitate de 99\%, achiziționarea de către elevi a unor cunoștințe, deprinderi, atitudini și acțiuni manifestate pe câmpul de interes afectat trăsăturilor de personalitate.

Analiza datelor privind valoarea şi dinamica coeziunii de grup, la clasa experimentală şi de control.

Acționările asupra rețelelor sociale și a trăsăturilor de personalitate a elevilor cuprinși în clasa experimentală, precum și investigarea sociometrică a clasei de control, care pe durata cercetării a participat la lecții de educație fizică tradiționale, au condus la punerea în evidență a dinamicii indicelui de coeziune pentru cele două grupuri.

Valorile obținute/etape de evaluare, sunt prezentate în Tab. 3.

Tabelul 3 Valorile coeficientului de coeziune/etape, rezultate pentru grupul experimental şi cel de control la Colegiul Naţional „Andrei Şaguna” - Braşov

\begin{tabular}{|l|c|c|}
\hline Etapa de intervenţie & $\begin{array}{c}\text { Valoarea coeficientului } \\
\text { de coeziune pentru } \\
\text { grupul experimental }\end{array}$ & $\begin{array}{c}\text { Valoarea coeficientului } \\
\text { de coeziune pentru } \\
\text { grupul control }\end{array}$ \\
\hline Etapa inițială & 0,023 & 0,021 \\
\hline Etapa intermediară 1 & 0,225 & 0,108 \\
\hline Etapa intermediară 2 & 0,531 & 0,203 \\
\hline Etapa finală & 0,603 & 0,316 \\
\hline
\end{tabular}

Comparând rezultatele obţinute pentru indicele de coeziune al grupului, în urma testării iniţiale, reiese faptul că ambele clase prezintă o coeziune slabă, coeficientul având valoarea mai mică de 0,21 (conform valorilor tabelare ale lui Matei, 1981). În continuare, la nivelul clasei experimentale, pe măsura aplicării metodologiei centrate pe unităţi/structuri de învăţare experienţiale, constând din jocuri motrice aplicate în diferite momente ale lecției, valoarea indicelui de 
coeziune a cunoscut - de la o etapă la alta - o creştere progresivă, grupul respectiv de elevi atingând - în final - un nivel de coeziune semnificativ (Tab. 3).

$\mathrm{Nu}$ acelaşi lucru îl putem spune despre clasa de control, asupra căruia nu s-a intervenit în cadrul procesului instructiv - educativ prin acţionări specifice (vezi variabila independentă), indicele de coeziune a acestuia ajungând doar la un nivelul de coeziune mică, valorile lui nedepăşind pragul de 0,4 (Tab. 3).

Reprezentările grafice ale progresiei valorilor obţinute, atât la clasa experimentală, cât şi la cea de control, sunt prezentate în figura 6. După cum se poate observa, creşterea valorică a coeficienţilor de coeziune rezultaţi/etapă la clasa experimentală, prezintă o ascensiune net superioară în raport cu clasa de control, unde s-au parcurs conţinuturile tradiţionale de educaţie fizică și sportivă. Acest fapt, ne determină să afirmăm că, mijloacele constând din diferite categorii de jocuri motrice, selecţionate şi adaptate mediului formal de instruire, precum şi aplicarea unei metodologii specifice de implementare a acestora în cadrul actului de predare-învăţare-evaluare, au determinat, în corelație cu ameliorarea rețelelor sociale și dezvoltarea trăsăturilor de personalitate a elevilor, creşterea semnificativă a coeziunii, la nivelul clasei experimentale.

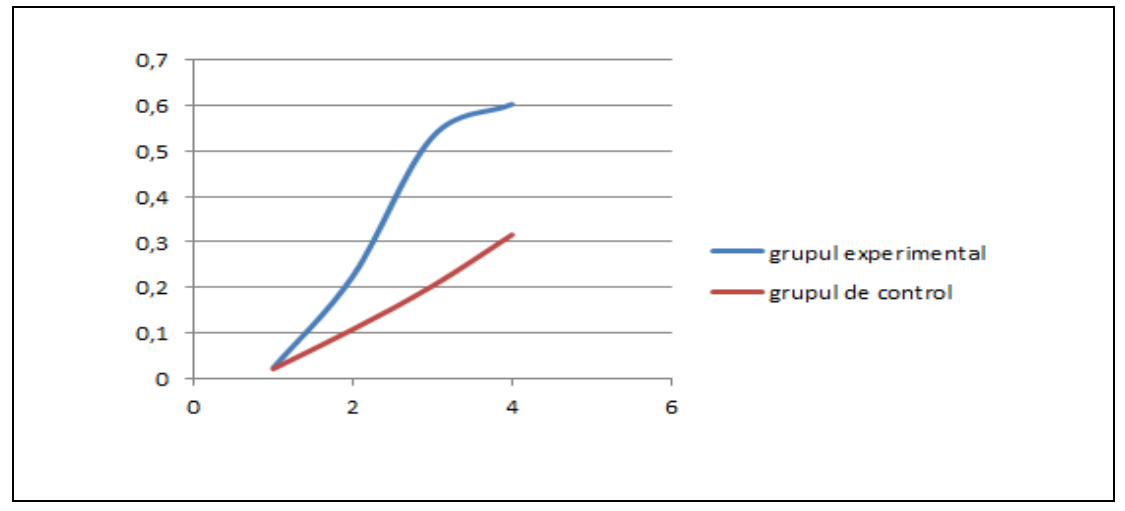

Figura 6. Dinamica coeziunii de grup pentru clasele experimentale şi de control la Colegiul Naţional „Andrei Şaguna” Braşov

\section{Concluzii}

În acord cu Sullivan (citat de Stoetzel, 1963, pp. 222-223) și noi considerăm că, la nivelul fiecărui individ, există imagini pozitive sau negative despre sine şi despre alţii, imagini durabile, formate în timp, dar şi imagini fluctuante, dinamice, datorate unor situaţii de moment. Funcţionarea relaţiilor interpersonale depinde nu numai de punerea în disponibilitate a uneia sau alteia dintre aceste sisteme de imagini existente, ci şi de natura combinaţiilor dintre ele. În cazul cercetării noastre, aceste combinații sunt date de valențele diferențiate ale celor şase categorii de jocuri motrice, de metodologia lor specifică de punere a acestora în scenă, în etapele de preimpact, impact, postimpact/revizuire. 
Dezvoltarea rețelelor sociale din cadrul unei clase, se realizează progresiv, pe baza unor evaluări permanente a acestora, a identificării de către cadrul didactic a elevilor, respectiv a diadelor, triadelor etc., care pot atrage cât mai mulți membri, în acțiuni de colaborare și cooperare cu responsabilitate, pentru realizarea scopurilor comun, dat de finalizarea fiecărui joc.

Datele cercetării confirmă faptul că, există o relaţie de directă proporţionalitate între prezenţa unor trăsături pozitive de personalitate şi şansa unui grup de a atinge un înalt nivel de coezivitate. În grupul experimental, unde s-a constatat treptat că rolurile au fost înţelese şi asumate, elevii au început să beneficieze de un status ridicat, liderii şi-au manifestat responsabilitatea, iar coezivitatea a tins să fie crescută. În acord cu această constatare, recomandăm angrenarea elevilor în conceperea, organizarea şi desfăşurarea unor activităţi colective, cu scenarii care au ca bază de derulare motricitatea umană, oferind astfel cât mai multe prilejuri de exteriorizare autentică, netrucată, nereţinută a trăsăturilor de personalitate, a concepţiilor şi atitudinilor achiziționate sau/și în curs de formare.

Activitatea experimentală a demonstrat că ameliorarea relaţiilor interpersonale și dezvoltarea trăsăturilor de personalitate, a determinat creșterea coeziunii clasei de elev, fapt pe care l-am realizat prin parcurgerea cu elevii a unor activităţi motrice formale, altele decât cele prezentate la rubrica „conţinuturi de învăţare” (tradiţionale), din de programa școlară de specialitate în vigoare - la disciplina Educație fizică (2009), prin selectarea și adecvarea unor categorii de activităţi motrice - jocuri motrice - ce își au originea în educaţia nonformală contemporană. 